\title{
Adrenal suppression from high-dose inhaled fluticasone propionate in children with asthma
}

\author{
D. Sim*, A. Griffiths*, D. Armstrong*, C. Clarke", C. Rodda", N. Freezer*,
}

\begin{abstract}
Adrenal suppression from high-dose inhaled fluticasone propionate in children with asthma. D. Sim, A. Griffiths, D. Armstrong, C. Clarke, C. Rodda, N. Freezer. (C) ERS Journals Ltd 2003.

ABSTRACT: This cross-sectional study was designed to examine the prevalence of adrenocortical suppression in children with asthma treated with high-dose inhaled fluticasone propionate (FP).

Children and adolescents $(n=50)$ with asthma, treated with inhaled $F P$ at a dose of $\geqslant 1,000 \mathrm{mg}$ a day for $\geqslant 6$ months, were enrolled. Early morning serum cortisol was performed. Subjects with a serum cortisol of $<400 \mathrm{nmol} \cdot \mathrm{L}^{-1}$ had a tetracosactrin stimulation test.

Fifty subjects of mean age $13.1 \mathrm{yrs}$ were treated with a mean dose of $924.7 \mu \mathrm{g} \cdot \mathrm{m}^{-2} \cdot \mathrm{day}^{-1}$ FP for a mean duration of 2 yrs. Of the 50 subjects, $36(72 \%)$ had serum cortisol levels of $<400 \mathrm{nmol} \cdot \mathrm{L}^{-1}$ and underwent tetracosactrin stimulation test. Of these, $6(17 \%)$ demonstrated a less than two-fold increase in serum cortisol from baseline and peak cortisol level of $\leqslant 550 \mathrm{nmol} \cdot \mathrm{L}^{-1}$ at 30 or 60 min poststimulation. There was a significant negative correlation between the dose of $\mathbf{F P} \cdot \mathbf{m}^{-2}$ and stimulated peak cortisol level.

Biochemical evidence of adrenocortical insufficiency was demonstrated in $12 \%$ of the subjects, indicating that high-dose fluticasone propionate use may be associated with dose-dependent adrenocortical suppression.

Eur Respir J 2003; 21: 633-636.
\end{abstract}

Depts of *Respiratory and Sleep Medicine and ${ }^{\#}$ Paediatric Endocrinology, Monash Medical Centre and "Centre for Heart and Chest Research, Monash University, Melbourne, Australia.

Correspondence: N. Freezer, Respiratory and Sleep Medicine, Monash Medical Centre, Melbourne, Australia.

Fax: 61395946415

E-mail: n.freezer@southernhealth.org.au

Keywords: Adrenal suppression

asthma

children

flixotide

Received: January 32002

Accepted after revision: May 252002
Inhaled corticosteroids are an important part of asthma management in children with frequent episodic or persistent asthma symptoms. Their use allows for a reduction in oral glucocorticoid use, better control of asthma and improved quality of life [1-3]. However, inhaled corticosteroids are known to be associated with dose-related systemic effects, and potential effects on the hypothalamic pituitary adrenal (HPA) axis, bone mineralisation and growth have been reported [4-6].

Fluticasone propionate (FP) is the most recent addition to the range of inhaled corticosteroids available in Australia. FP may produce greater dose-related adrenal suppression than budesonide or beclomethasone [3]. This observation has been explained by FP's high glucocorticoid receptor affinity and high lipophilicity, which result in greater tissue distribution, prolonged pulmonary receptor occupancy and longer plasma half-life [4, 7-10]. After repeated doses, FP demonstrates a moderate degree of accumulation [8,9]. It has been suggested that such accumulation may play a more important role in HPA axis suppression than peak plasma concentrations [10, 11].

HPA axis suppression over a prolonged period of time can result in adrenal cortical atrophy [4]. This condition can predispose a person to life-threatening acute adrenal insufficiency if the adrenal cortex is unable to generate an adequate endogenous cortisol response to a stressful condition or when corticosteroid therapy is abruptly ceased.

Data from adult studies suggest that FP in doses of $>750 \mu \mathrm{g} \cdot \mathrm{day}^{-1}$ is associated with suppression of the HPA axis [4]. Paediatric studies suggest that FP in doses of $\leqslant 400 \mu \mathrm{g} \cdot \mathrm{day}^{-1}$ does not produce significant systemic adverse effects [4, 11-13].

The effects of higher doses of inhaled FP in children with asthma are unclear. Published case reports have described FP-induced growth retardation [14], Cushing's syndrome [15] and adrenal suppression $[14,16]$ in children with asthma receiving doses ranging $250-2,250 \mu \mathrm{g} \cdot \mathrm{day}^{-1}$. There have been few studies examining HPA axis suppression in children with asthma treated with FP at high doses and the prevalence rate of such adverse effects at these high doses of FP is unclear.

Measures of HPA axis function are a sensitive method of assessing the systemic effects of inhaled corticosteroid therapy [10]. In addition, measuring the cortisol response to a stimulation test allows evaluation of the adrenal reserve, hence the risk of adrenal insufficiency during periods of illness or stress.

The aim of this cross-sectional study was to determine the prevalence of HPA axis suppression in children with asthma on long-term treatment with high-dose inhaled prophylactic FP.

\section{Materials and methods}

\section{Study subjects}

Children and adolescents with asthma were recruited from asthma clinics at Monash Medical Centre, Melbourne, Australia, from August 1999-August 2000. Inclusion criteria were subjects with chronic asthma with a dose of FP titrated to a minimum effective dose of $\geqslant 1,000 \mu \mathrm{g} \cdot \mathrm{day}^{-1}$ for a duration of $\geqslant 6$ months prior to enrolment. Subjects were excluded if they had another chronic illness, were known to be nonadherent with asthma therapy or had received oral or systemic steroids during the study period or within 2 weeks of enrolment. All subjects were on a twice-daily dosage regimen, used either a metered-dose inhaler (MDI) with spacer device 
or Accuhaler $\AA$ (GlaxoSmithKline, Melbourne, Australia) delivery system, and had been routinely instructed to mouth rinse after FP administration. The study was approved by the Southern Health Care Network Human Research and Ethics Committee and informed consent was obtained from all subjects and their legal guardian.

\section{Study design}

A baseline early morning serum cortisol specimen was obtained from all subjects between 08:00-10:00 h. Those subjects with a morning serum cortisol level $<400 \mathrm{nmol} \cdot \mathrm{L}^{-1}$ underwent a short tetracosactrin stimulation test to evaluate their adrenal reserve.

\section{Methods}

In the paediatric population, significant interpatient variability exists in the normal endogenous activity of the HPA axis [17]. Published reference ranges for normal serum cortisol levels in children are wide [18, 19] and there has been uncertainty about what levels of early morning serum cortisol would unequivocally indicate normal HPA function [20]. For the purposes of this study, a threshold level of $400 \mathrm{nmol} \cdot \mathrm{L}^{-1}$ for early morning serum cortisol was selected, based on the reference range in clinical use by the pathology laboratories at the authors' institution [18].

All subjects were withheld from FP therapy for $\geqslant 30 \mathrm{~h}$ prior to collection of early morning serum cortisol specimens. All specimens were collected by venepuncture between 08:00-10:00 h. Subjects with a morning serum cortisol level of $\geqslant 400 \mathrm{nmol} \cdot \mathrm{L}^{-1}$ were deemed to have normal adrenal function.

Subjects with morning serum cortisol levels $<400 \mathrm{nmol} \cdot \mathrm{L}^{-1}$ underwent a short tetracosactrin stimulation test involving the intramuscular injection of $250 \mu \mathrm{g}$ tetracosactrin (Synacthen; Novartis Pharmaceuticals Australia Ltd, Sydney, Australia) with serum cortisol samples taken at 0,30 and 60 min by venepuncture, following the application of a eutectic mixture of local anaesthetic cream (Astrazeneca Pty Ltd, Sydney, Australia). A normal response was defined as achieving a stimulated cortisol value of $\geqslant 550 \mathrm{nmol} \cdot \mathrm{L}^{-1}$ with a two-fold or greater increase from baseline cortisol value [21]. The serum cortisol specimens were assayed at the Biochemistry Unit of the Department of Pathology, Southern Health Care Network (Melbourne, Australia) using an Immulite immunoassay (Diagnostic Products Corporation, Los Angeles, CA, USA).

Adherence to medication was assessed indirectly by subject and parent interview, serial forced expiratory volume in one second measurements, and clinic and hospital attendance records. Symptoms suggestive of adrenal insufficieny (fatigue, unexpected weight loss, anorexia, faints, prolonged recovery from intercurrent illnesses) were sought in the interviews.

\section{Statistical analysis}

This cross-sectional study determined the prevalence of adrenal suppression in a population of children with asthma treated with high-dose FP. The results were examined to determine whether a significant dose/effect correlation existed. Pearson's product moment correlation coefficient (r) was obtained. As some of the data was nonparametric, Spearman's coefficient was also calculated. The null hypothesis

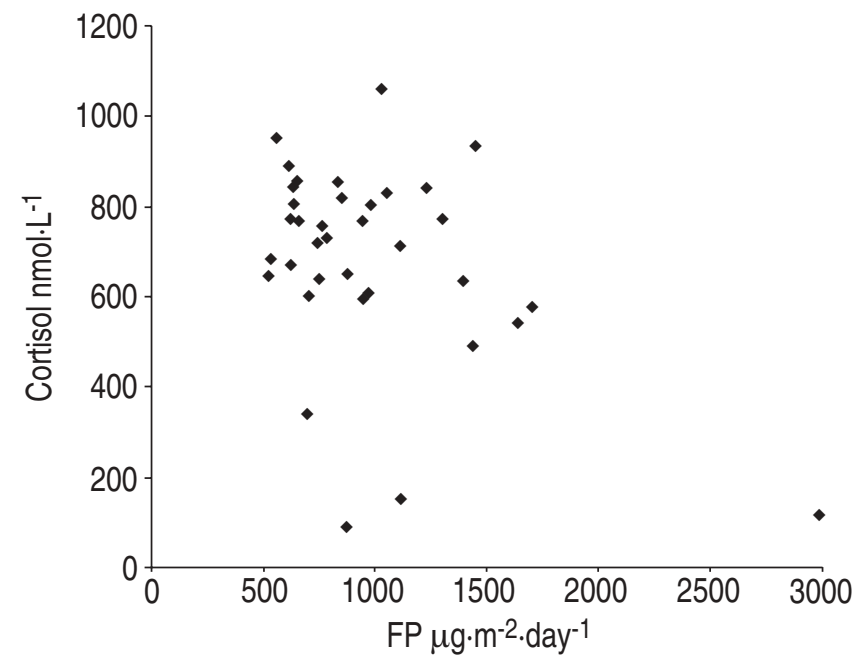

Fig. 1. - Peak stimulated cortisol levels. FP: fluticasone propionate.

was rejected if statistical significance, defined as a $\mathrm{p}<0.05$, was obtained.

\section{Results}

Potential subjects $(n=69)$ were identified from clinic records and 50 were enrolled. Nineteen children were excluded for reasons of coexisting endocrine condition (two subjects), recent oral steroid therapy (six subjects), self-declared poor adherence to prophylactic asthma therapy (four subjects), recent reduction in dose of FP to $<1,000 \mu \mathrm{g} \cdot \mathrm{day}^{-1}$ (four subjects) and refusal to consent to tetracosactrin stimulation test (three subjects). None reported any symptoms suggestive of adrenal insufficiency.

The subjects were of median age $13.5 \mathrm{yrs}$ (range 4-20 yrs) and had been treated with a mean FP dose of $1,280 \mu \mathrm{g} \cdot$ day $^{-1}$ or $924.7 \mu \mathrm{g} \cdot \mathrm{m}^{-2} \cdot$ day $^{-1}$ (range $476-2,985 \mu \mathrm{g} \cdot \mathrm{m}^{-2} \cdot$ day $^{-1}$ ) for a mean duration of 2 yrs (range $0.5-5$ yrs).

Early morning serum cortisol levels were obtained from all of the 50 enrolled subjects. The mean level was $318 \mathrm{nmol} \cdot \mathrm{L}^{-1}$ (median $256 \mathrm{nmol} \cdot \mathrm{L}^{-1}$, range $27-927 \mathrm{nmol} \cdot \mathrm{L}^{-1}$ ). Baseline early morning serum cortisol levels $<400 \mathrm{nmol} \cdot \mathrm{L}^{-1}$ were demonstrated by 36 subjects $(72 \%)$.

All 36 subjects who demonstrated a low early morning cortisol level underwent a short tetracosactrin stimulation test. The mean stimulated peak cortisol level was $681 \mathrm{nmol} \cdot \mathrm{L}^{-1}$ (median $725 \mathrm{nmol} \cdot \mathrm{L}^{-1}$, range $89-1,063 \mathrm{nmol} \cdot \mathrm{L}^{-1}$ ). Six subjects $(17 \%)$ demonstrated a stimulated peak serum cortisol level of $<550 \mathrm{nmol} \cdot \mathrm{L}^{-1}$ or a less than two-fold increase from baseline level and therefore demonstrated biochemical evidence of adrenal insufficiency. Of these subjects, three had a baseline serum cortisol of $<100 \mathrm{nmol} \cdot \mathrm{L}^{-1}$ and were thus commenced on hydrocortisone replacement therapy $\left(10-15 \mathrm{mg} \cdot \mathrm{m}^{-2} \cdot\right.$ day $\left.^{-1}\right)$ for $\geqslant 2$ months before the dose was weaned over a period of 3 months.

A negative correlation between the absolute dose of FP received and stimulated peak cortisol level of $-0.35(\mathrm{p}=0.034)$ was demonstrated. This correlation improved to $-0.42(\mathrm{p}=0.010)$ when the dose of FP was corrected for body surface area (fig. 1). Spearman's correlation coefficient reduced the effect of the outlier $\left(\mathrm{r}_{\mathrm{s}}=-0.33, \mathrm{p}=0.08\right)$ but did not eliminate it completely. The correlation between the baseline early morning serum cortisol level and the absolute FP dose received ( $r=-0.099$, $\mathrm{p}=0.493$ ) was not statistically significant. This correlation strengthened slightly $(\mathrm{r}=-0.134, \mathrm{p}=0.353)$ when the FP dose 
was corrected for body surface area but still failed to reach statistical significance.

\section{Discussion}

This study suggests that a significant number of paediatric patients receiving high-dose inhaled FP have biochemical evidence of adrenal suppression. This finding has implications for the management of intercurrent illnesses in these patients as well as their asthma.

This study demonstrated a significant negative correlation between the absolute dose of FP and the peak stimulated cortisol level. Statistically, this relationship improved when the dose of FP was corrected for body surface area. A similar dose/effect relationship was previously demonstrated by PRIFTIS et al. [5] in children receiving beclomethasone.

There was no significant correlation between the dose of FP and the baseline early morning serum cortisol level. It was previously suggested that early morning cortisol levels are less sensitive in screening for adrenal suppression [22]. It was observed that up to a three-fold difference in cortisol levels may occur within an individual between 08:00-10:00 h [17]. These findings would suggest that an adrenal stimulation test is required to make a diagnosis of adrenal insufficiency.

The results of this study support the findings of FITZGERALD et al. [23], who found that $67 \%$ of children receiving $750 \mu \mathrm{g} \cdot \mathrm{day}^{-1}$ of FP for 12 weeks had subnormal low-dose synacthen-stimulated peak serum cortisol levels. KANNISTO et al. [24] concluded that $23 \%$ of their study cohort treated with $500 \mu \mathrm{g} \cdot \mathrm{day}^{-1} \mathrm{FP}$ or $800 \mu \mathrm{g} \cdot \mathrm{day}^{-1}$ budesonide had subnormal cortisol responses after a low-dose adrenocorticotrophic hormone (ACTH) stimulation test. Using a similar low-dose ACTH test, BROIDE et al. [25] found that $35 \%$ of children treated with a mean dose of $500 \mu \mathrm{g} \cdot \mathrm{m}^{-2} \cdot \mathrm{day}^{-1}$ of budesonide or bethamethasone had a subnormal cortisol response.

The systemic bioavailability of FP may differ when various delivery devices are compared and other authors suggest that the risk of adverse systemic side-effects is proportional to the total body dose received. NEWMAN and coworkers [26, 27] have shown that in asthmatic patients, the total body dose of a drug delivered by MDI and spacer is approximately onehalf that from a dry-powder inhaler (DPI) or MDI without a spacer (38\% MDI plus spacer versus $86 \%$ DPI, 90\% MDI alone). As the lung deposition from the delivery devices is similar $(15-25 \%)$, the difference is primarily the high oral deposition of the drug inhaled from DPIs or MDIs alone (72\% DPI, 81\% MDI versus $17 \%$ MDI plus spacer). Although the present study's numbers were too small to allow stratification of results by device, all patients with MDIs were instructed to use a spacer, and all patients were instructed to mouth rinse and spit out to reduce oral deposition and therefore total body dose received.

Self-reported adherence with FP was satisfactory in this study (mean 91.4\%). Noncompliance with medications is still a potential confounder, which may have led to underestimation of the effect of FP on adrenal function in this study. However, given that almost one-quarter of the patients were on $>1,000 \mu \mathrm{g} \cdot \mathrm{day}^{-1}$, many would still meet the study inclusion criteria despite some reduction in adherence.

This study may have underestimated the number of subjects with impaired adrenal function by the use of a conventional dose $(250 \mu \mathrm{g})$, short synacthen stimulation test (SST). It has been suggested that the low-dose $(0.5-1.0 \mu \mathrm{g} \cdot 1.73 \mathrm{~m}$ body surface area ${ }^{-2}$ ) short synacthen test (LDSST) may be more sensitive than the SST in revealing cases of mild adrenal insufficiency [20, 25, 28-30]. However, ABDU et al. [31] found that using the LDSST alone to diagnose adrenal insufficiency lacked specificity with an $11 \%$ false-positive rate. The present authors chose to use the SST for this study as it is the standard clinical screening test for adrenal insufficiency in the paediatric population at the hospital, thus maintaining consistency with their current clinical practice. Moreover, the validity of the SST as a screening investigation has been reaffirmed by recent studies where it has been compared with the reference standard insulin tolerance test [22, 31-33].

In summary, the results of this study indicate that significant dose-related adrenal suppression may occur with high-dose inhaled FP used over a period of $\geqslant 6$ months. An early morning serum cortisol level of $<400 \mathrm{nmol} \cdot \mathrm{L}^{-1}$ suggests the presence of adrenal suppression and an adrenal stimulation test is required for diagnosis. In the absence of stressful stimuli, these children would probably not report any clinical symptoms of adrenal insufficiency. Those who have a very low baseline serum cortisol $\left(<100 \mathrm{nmol} \cdot \mathrm{L}^{-1}\right)$ may require maintenance hydrocortisone replacement therapy with a twoto three-fold dose increase for $48-72 \mathrm{~h}$ during periods of stress, fever or illness to minimise the risk of an adrenal crisis.

The risk of adrenal insufficiency from high-dose inhaled corticosteroids may be minimised by following the asthma management guidelines of the National Asthma Council [1] and British Thoracic Society [2]. Both recommend using the minimum effective dose of inhaled corticosteroids to control a patient's asthma, administering inhaled steroids via an ageappropriate delivery system and the routine use of mouthrinsing following each dose in older children and adolescents, particularly if dry-powder inhalers or metered-dose inhalers without spacers are used.

\section{References}

1. National Asthma Council. Asthma Management Handbook. 4th Edn. Melbourne, National Asthma Council, 2002.

2. British Thoracic Society. The British guidelines on asthma management. Thorax 1997; 52: Suppl. 1, S1-S2.

3. Calpin C, Macarthur C, Stephens D, Feldman W, Parkin PC. Effectiveness of prophylactic inhaled steroids in childhood asthma: a systemic review of the literature. J Allergy Clin Immunol 1997; 100: 452-457.

4. Lipworth BJ. Systemic adverse effects of inhaled corticosteroid therapy - a systematic review and meta-analysis. Arch Intern Med 1999; 159: 941-955.

5. Priftis K, Milner AD, Conway E, Honour JW. Adrenal function in asthma. Arch Dis Child 1990; 65: 838-840.

6. Doull IJM, Freezer NJ, Holgate ST. Growth of prepubertal children with mild asthma treated with inhaled beclomethasone dipropionate. Am J Respir Crit Care Med 1994; 151: 1715-1719.

7. Lipworth BJ. New perspectives on inhaled drug delivery and systemic bioactivity. Thorax 1995; 50: 105-110.

8. Meibohm B, Mollmann H, Wagner M, Hochhaus $G$, Mollman A, Derendorf $H$. The clinical pharmacology of fluticasone propionate. Rev Contemp Pharmacother 1998; 9: 535-549.

9. Todd GRC. Side-effects of high-dose fluticasone propionate in children. Eur Respir J 1999; 13: 707-709.

10. O'Byrne PM, Pedersen S. Measuring efficacy and safety of different inhaled corticosteroid preparations. J Allergy Clin Immunol 1998; 102: 879-886.

11. Thorsson L, Dahlstrom K, Edsbacker S, Kallen A, Paulson J, Wiren JE. Pharmacokinetics and systemic effects of inhaled fluticasone propionate in healthy subjects. Br J Clin Pharmacol 1997; 43: 155-161.

12. Ferguson AC, Spier S, Manjra A, Versteegh F, Mark S, Zhang P. Efficacy and safety of high-dose inhaled steroids in children with asthma: a comparison of fluticasone propionate and budesonide. J Pediatr 1999; 134: 422-426.

13. Lipworth BJ, Clark DJ, MacFarlane LC. Adrenocortical 
activity with repeated twice daily dosing of fluticasone propionate and budesonide given via a large volume spacer to asthmatic school children. Thorax 1997; 52: 686-689.

14. Todd G, Dunlop K, McNaboe J, Ryan MF, Carson D, Shields MD. Growth and adrenal suppression in asthmatic children treated with high-dose fluticasone propionate. Lancet 1996; 348: 27-29.

15. Taylor AV, Laoprasert N, Zimmerman D, Sachs M. Adrenal suppression secondary to inhaled fluticasone propionate Ann Allergy Asthma Immunol 1999; 83: 68-70.

16. Zimmerman B, Gold M, Wherrett D, Hanna A. Adrenal suppression in two patients with asthma treated with low doses of the inhaled steroid fluticasone propionate. J Allergy Clin Immunol 1998; 101: 425-426.

17. Williams J. Fluticasone propionate in the treatment of asthma in children: efficacy and safety. Rev Contemp Pharmacother 1998; 9: 581-590.

18. Jonetz-Mentzel L, Wiedemann G. Establishment of reference ranges for cortisol in neonates, infants, children and adolescents. Eur J Clin Chem Biochem 1993; 31: 525-529.

19. Fisher DA, Horton R, Ladenson PW, Nelson JC, Odell WD, eds. Endocrinology - Test Selection and Interpretation. 2nd Edn. Quest Diagnostics Incorporated, San Juan, 1998; p. 71

20. Tordjman K, Jaffe A, Grazas N, Apter C, Stern N. The role of low dose $(1 \mathrm{mcg})$ adrenocorticotropin test in the evaluation of patients with pituitary diseases. $J$ Clin Endocrinol Metab 1995; 80: 1301-1305.

21. Walker JM, Hughes IA. Tests and normal values in paediatric endocrinology. In: Brook CJD, ed. Clinical Paediatric Endocrinology. London, Blackwell Science, 1995; pp. 789-790.

22. Clayton RN. Diagnosis of adrenal insufficiency. BMJ 1989; 298: 271-272.

23. Fitzgerald D, van Asperen P, Mellis C, Honner M, Smith L, Ambler G. Fluticasone propionate $750 \mathrm{mcg} /$ day versus beclomethasone dipropionate $1500 \mathrm{mcg} /$ day: comparison of efficacy and adrenal function in paediatric asthma. Thorax 1998; 53: 656-661.
24. Kannisto S, Korpi M, Remes K, Voutilainen R. Adrenal suppression, evaluated by a low dose adrenocorticotropin test, and growth in asthmatic children treated with inhaled steroids. J Clin Endocrinol Metab 2000; 85: 652-657.

25. Broide J, Soferman S, Kivity S, et al. Low dose adrenocorticotropin test reveals impaired adrenal function in patients taking inhaled corticosteroids. J Clin Endocrinol Metab 1995; 80: 1243-1246.

26. Newman SP, Millar AB, Lennard-Jones TR, Moren F, Clarke SW. Improvement of pressurised aerosol deposition with Nebuhaler spacer device. Thorax 1984; 39: 935-941.

27. Newman SP, Moren F, Trofast E, Talaee N, Clarke SW. Deposition and clinical efficacy of terbutaline sulfate from Turbuhaler. A new multi-dose powder inhaler. Eur Respir $J$ 1989; 2: 247-252.

28. Crowley S, Hindmarsh PC, Holownia JW. The use of low doses of ACTH in the investigation of adrenal function in man. J Endocrinol 1991; 130: 475-479.

29. Rasmuson S, Olsson T, Hagg E. A low dose ACTH test to assess the function of the hypothalamic-pituitary-adrenal axis. Clin Endocrinol 1996; 44: 151-156.

30. Agwu JC, Spoudeas H, Hindmarsh PC, Pringle PJ, Brook CGD. Tests of adrenal insufficiency. Arch Dis Child 1999; 80: 330-333.

31. Abdu T, Elhadd T, Neary R, Clayton R. Comparison of the low dose short synacthen test $(1 \mathrm{mcg})$, the conventional dose short synacthen test $(250 \mathrm{mcg})$ and the insulin tolerance test for assessment of the hypothalamo-pituitary-adrenal axis in patients with pituitary disease. J Clin Endocrinol Metab 1999; 84: 838-843.

32. Hurel SJ, Thompson CJ, Watson J, Harris M, Bayliss PH, Kendall-Taylor P. The short synacthen test and insulin stress tests in the assessment of the hypothalamic-pituitary-adrenal axis. Clin Endocrinol 1996; 44: 141-146.

33. Brown PH, Blundell G, Greening AP, Crompton GK. Screening for hypothalamo-pituitary-adrenal axis suppression in asthmatics taking high dose inhaled corticosteroids. Respir Med 1991; 85: 511-516. 